\title{
EDITORIAL
}

\section{Inhaled steroids in children: adrenal suppression and growth impairment}

\author{
K-H. Carlsen*, J. Gerritsen ${ }^{\#}$
}

Inhaled steroids have been used for many years. The first report of their beneficial use in asthmatic children was published almost 30 yrs ago [1]. With increasing knowledge of the side-effects of systemically administered steroids, there has been a steady increase in the use of inhaled steroids, and they are presently considered to be the most important treatment for asthma. Inhaled steroids are the cornerstone of all guidelines on asthma treatment [2-4]. They reduce symptoms in children with asthma [5], improve quality of life in asthmatic children and their families [6], decrease patients' and their parents' absence from school/work [7], reduce airway inflammation [8], and improve lung function [9], bronchial responsiveness [10] and exercise-induced asthma [11, 12]. The sale and use of inhaled steroids has markedly increased in Nordic countries since the late 1980s, which has probably had an impact upon the admission rate of childhood asthma in these countries. In older children, the admission [13] and particularly readmission [14] rates for acute asthma have decreased in these countries. The use of inhaled steroids has thus had a major impact upon daily life and the "mastering" of asthma in asthmatic children.

Despite the beneficial effects of inhaled steroids in childhood asthma, general agreement as to how early to start treatment has not been reached. This is mostly due to the general fear of the side-effects of inhaled steroids, but also because of an awareness of the possible effects upon lung growth in young children, as has been reported by the use of systemic steroids in animal experiments [15].

The local side-effects of inhaled steroids on skin, the mucous membranes of the respiratory tract, and the oropharyngeal area are also well known, but have received much less attention than the systemic sideeffects. The local side-effects consist of perioral dermatitis, oral candidiasis, hoarseness, dysphonia, cough during inhalation and a feeling of thirst [16].

However, systemic side-effects, including suppression of the hypothalamic-hypophyseal-adrenal axis [17-19], a possible reduction in growth velocity caused

\footnotetext{
*Voksentoppen National Hospital and Kloster Foundation, Research Institute of Asthma, Allergy and Chronic Lung Diseases in Children, Oslo, Norway. "Beatrix Children's Hospital, University Hospital Grooningen, Grooningen, the Netherlands.

Correspondence: Voksentoppen National Hospital and Kloster Foundation, Research Institute of Asthma, Allergy and Chronic Lung Diseases in Children, Ullveien 14, N-0791 Oslo, Norway. Fax: 47 22136505. E-mail: k.h.carlsen@klinmed.uio.no
}

by inhaled steroids [20], effects upon bone structure and bone mass [21], markers of bone turnover [22] and carbohydrate and lipid metabolism [23], weight gain and Cushing's Syndrome [24], cause the most concern. Posterior subcapsular cataracts have been described as developing after systemic steroids have been used and, in three patients, on inhaled beclomethasone dipropionate with occasional short courses of systemic steroids over several years [25]. However, systematic studies have not indicated an increased risk of cataracts with the use of inhaled steroids [26, 27].

Although practical experience throughout the past 30 yrs has proved that inhaled steroids are safe drugs for most patients, it has also been shown that in higher doses, a systemic effect is detectable by demonstrating an early morning dip in serum cortisol when measuring 24-h integrated and fractionated (overnight, $08.00 \mathrm{~h}$, daytime) serum cortisol levels and urinary cortisol/creatinine excretion [28, 29]. Stimulation tests have also been used to detect the effect of inhaled steroids on the hypothalamicpituitary-adrenal axis [29]. After a meta-analysis including 27 studies performed during 1966-1998, it was concluded that using $>1.5 \mathrm{mg}$ inhaled steroid $\cdot$ day $^{-1}$ resulted in a marked adrenal suppression [30]. The studies included both healthy volunteers and asthmatic adults and children. In contrast, Russell [31] noted that the risk of adrenal suppression and growth retardation was present when doses exceeded $400 \mu \mathrm{g}$ of inhaled beclomethasone dipropionate or budesonide per day in children. It has been observed that a marked individual variation in the degree of adrenal suppression caused by use of inhaled steroids occurs. PRIFTIS et al. [24] reported an asthmatic child who developed a marked Cushingoid appearance and evidence of adrenal suppression and growth reduction while on a low dose of inhaled steroid. There was an improvement in the appearance, regression of adrenal suppression and improved growth when inhaled steroids were replaced by disodium cromoglycate.

Some studies have indicated varying degrees of adrenal suppression with different inhaled steroids. The results of the studies, however, have not been consistent. In a meta-analysis including seven trials comparing inhaled fluticasone propionate with inhaled budesonide and seven trials comparing inhaled fluticasone propionate with inhaled beclomethasone propionate, no difference in serum cortisol was found between fluticasone and budesonide in lower doses, but less suppression by fluticasone than 
budesonide was found in higher doses. No differences were found when comparing fluticasone and beclomethasone dipropionate [32]. However, in the metaanalysis including 27 studies previously referred to, LIPWORTH [30] reported that adrenal suppression occurred with a lower dose of fluticasone propionate than with other inhaled steroids. TodD et al. [33] reported growth and adrenal suppression in six children with fluticasone propionate at a daily dose of $\geqslant 1,000 \mu \mathrm{g} \cdot \mathrm{day}^{-1}$ [33]. With regards to asthmatic children, it should be noted that PRIFTIS et al. [34] recommended that endocrine assessment should be performed when prescribing inhaled steroids in daily doses comparable to beclomethasone dipropionate $(\geqslant 400 \mu \mathrm{g})$.

In this issue of the European Respiratory Journal, ToDD et al. [35] report on the most severe form of adrenal suppression, acute adrenal crisis, in four asthma patients aged 7-33 yrs taking fluticasone propionate in high doses $\left(>1,000 \mu \mathrm{g} \cdot \mathrm{day}^{-1}\right)$. All patients were acutely ill due to severe adrenergic hypofunction. Three of the patients, all children aged 7-9 yrs, presented with acute hypoglycaemic convulsions. This study particularly underlines two important issues. 1) It is important to look for adrenal suppression in children treated with inhaled steroids and to assess adrenal function. 2) There is a marked individual variation in the systemic response to inhaled steroids, and even in moderately high doses, severe adrenal suppression may occur.

The other most widely recognized and feared systemic side-effect of inhaled steroids in children is growth retardation. Severe asthma may affect growth in children. BALFOUR-LYNN [36] performed a longterm follow-up study of 66 children with severe asthma. A delay in the onset of puberty in asthmatic children was found, giving the impression of growth retardation, but with a later "catch-up" growth, thus allowing the asthmatic children to reach normal adult height. Growth impairment caused by inhaled steroids has been reported in a number of studies. However, in a meta-analysis, Allen et al. [37] evaluated 95 articles and included 21 studies involving 810 patients. Both oral and inhaled steroids were assessed and it was concluded that a significant, though weak impairment was found for oral steroids, whereas inhaled beclomethasone dipropionate was not associated with growth impairment, but with attaining normal final stature. Several ways to assess growth have been developed. Short-term growth has been assessed by measurement of knemometry in the lower leg, and has shown significant short-term impairment of growth in a number of studies including oral and other inhaled steroids [38-40]. The long-term significance of measuring short-term growth has been questioned, and thus careful studies have been performed, including studies with lower doses of inhaled steroids. In children with mild asthma, a significant though small reduction in growth was seen with the use of beclomethasone dipropionate compared double-blind with a placebo [20] or theophylline [41]. In a study by Doull et al. [42], a second analysis showed that a reduction in growth was found, for the most part, during the first 6 weeks of treatment [42]. Even in mildly asthmatic children on low-dose inhaled steroids (budesonide), a small but significant reduction in growth was found after 12 months compared to placebo in prepubertal (7-11 yrs) but not older children [43]. However, the clinical significance of a growth retardation of $1 \mathrm{~cm}$ may be questioned. In a long-term follow-up study of asthmatic children treated with inhaled budesonide over several years, Agertoft and Pedersen [9] concluded that, even after many years of treatment with inhaled steroids, children on inhaled steroids reached normal adult height. However, measurement of growth is important in the assessment of the possible systemic effects of inhaled steroids.

The studies reporting on possible growth impairment by inhaled steroids are very different, varying in type and dosage of the drug, ways of measuring growth, duration of follow-up, type of patients included with regard to the relationship between type and severity of asthma, age and use of other concomitant treatment for asthma, thus making it difficult to reach final conclusions. In this issue of the European Respiratory Journal, PRICE et al. [44] address this matter in a most comprehensive manner. In their first article they take the diverse factors into consideration, classifying the different types of studies and making recommendations as to how studies assessing growth and final height in asthmatic children using inhaled steroids should be set-up and conducted. Groups planning to set-up studies on this topic should read the article carefully and take their recommendations into consideration.

In their second article, PRICE et al. [45] present a systematic review of the effect of asthma therapy on growth in children based upon their own classification of studies as given in their first article [44].

Thus, in this issue of the European Respiratory Journal, the effect of inhaled steroids upon adrenal function with the possibility of severe systemic reactions [35], the effect of inhaled steroids upon growth and final height [44, 45] and two different and important aspects of the systemic side-effects of inhaled steroids when used in asthmatics are discussed. All three articles highlight the necessity of assessing and monitoring the asthmatic child treated with inhaled steroids, taking individual variations into consideration, and PRICE and co-workers [44, 45] outline the necessity for careful design and conduct of clinical research studies on the systemic effects of inhaled steroids.

\section{References}

1. Morrison Smith J. A clinical trial of beclomethasone dipropionate aerosol in children and adolescents with asthma. Clin Allergy 1973; 3: 249-253.

2. Dahl R, Bjermer L. Nordic consensus report on asthma management. Nordic Asthma Consensus Group. Respir Med 2000; 94: 299-327.

3. Warner JO, Naspitz CK. Third International Pediatric Consensus statement on the management of childhood asthma. International Pediatric Asthma Consensus Group. Pediatr Pulmonol 1998; 25: 1-17. 
4. Anonymous. Guidelines for the diagnosis and management of asthma. National Heart, Lung, and Blood Institute. National Asthma Education Program. Expert Panel Report. J Allergy Clin Immunol 1991; 88: 425-534.

5. Long-term effects of budesonide or nedocromil in children with asthma. The Childhood Asthma Management Program Research Group. $N$ Engl J Med 2000; 343: 1054-1063.

6. Mahajan P, Pearlman D, Okamoto L. The effect of fluticasone propionate on functional status and sleep in children with asthma and on the quality of life of their parents. J Allergy Clin Immunol 1998; 102: 19-23.

7. Weiss K. The impact of pharmacologic therapy on the costs of asthma. Allergy Proc 1994; 15: 189-192.

8. Kristjansson S, Strannegard IL, Strannegard O, Peterson C, Enander I, Wennergren G. Urinary eosinophil protein $\mathrm{X}$ in children with atopic asthma: a useful marker of antiinflammatory treatment. J Allergy Clin Immunol 1996; 97: 1179-1187.

9. Agertoft L, Pedersen S. Effect of long-term treatment with inhaled budesonide on adult height in children with asthma. N Engl J Med 2000; 343: 1064-1069.

10. van Essen-Zandvliet EE, Hughes MD, Waalkens HJ, et al. Effects of 22 months of treatment with inhaled corticosteroids and/or beta-2-agonists on lung function, airway responsiveness, and symptoms in children with asthma. The Dutch Chronic Non-specific Lung Disease Study Group. Am Rev Respir Dis 1992; 146: $547-554$

11. Henriksen JM, Dahl R. Effects of inhaled budesonide alone and in combination with low-dose terbutaline in children with exercise-induced asthma. Am Rev Respir Dis 1983; 128: 993-997.

12. Jonasson G, Carlsen KH, Hultquist C. Low-dose budesonide improves exercise-induced bronchospasm in schoolchildren. Pediatr Allergy Immunol 2000; 11: $120-125$.

13. Wennergren G, Kristjansson S, Strannegard IL. Decrease in hospitalization for treatment of childhood asthma with increased use of antiinflammatory treatment, despite an increase in the prevalence of asthma. J Allergy Clin Immunol 1996; 97: 742-748.

14. Jonasson G, Lodrup Carlsen KC, Leegaard J, Carlsen $\mathrm{KH}$, Mowinckel P, Halvorsen KS. Trends in hospital admissions for childhood asthma in Oslo, Norway, 1980-95. Allergy 2000; 55: 232-239.

15. Rotschild A, Solimano A, Sekhon HS, Massoud EA, Thurlbeck WM. Effect of triamcinolone acetonide on the development of the pulmonary airways in the fetal rat. Pediatr Pulmonol 1997; 23: 76-86.

16. Dubus JC, Marguet C, Deschildre A, et al. Local side effects of inhaled corticosteroids in asthmatic children: Influence of drug, dose, age and device. Allergy 2001; 56: 944-948.

17. Yiallouros PK, Milner AD, Conway E, Honour JW. Adrenal function and high dose inhaled corticosteroids for asthma. Arch Dis Child 1997; 76: 405-410.

18. Hedlin G, Svedmyr J, Ryden AC. Systemic effects of a short course of betamethasone compared with highdose inhaled budesonide in early childhood asthma. Acta Paediatr 1999; 88: 48-51.

19. Goldberg S, Algur N, Levi M, et al. Adrenal suppression among asthmatic children receiving chronic therapy with inhaled corticosteroid with and without spacer device. Ann Allergy Asthma Immunol 1996; 76: 234-238.
20. Doull IJM, Freezer NJ, Holgate ST, Doull IJ. Growth of prepubertal children with mild asthma treated with inhaled beclomethasone dipropionate. Am J Respir Crit Care Med 1995; 151: 1715-1719.

21. Martinati LC, Bertoldo F, Gasperi E, Micelli S, Boner AL. Effect on cortical and trabecular bone mass of different anti-inflammatory treatments in preadolescent children with chronic asthma. Am J Respir Crit Care Med 1996; 153: 232-236.

22. Rao R, Gregson RK, Jones AC, Miles EA, Campbell MJ, Warner JO. Systemic effects of inhaled corticosteroids on growth and bone turnover in childhood asthma: a comparison of fluticasone with beclomethasone. Eur Respir J 1999; 13: 87-94.

23. Turpeinen M, Sorva R, Juntunen-Backman K. Changes in carbohydrate and lipid metabolism in children with asthma inhaling budesonide. J Allergy Clin Immunol 1991; 88: 384-389.

24. Priftis K, Everard ML, Milner AD. Unexpected sideeffects of inhaled steroids: a case report. Eur J Pediatr 1991; 150: 448-449.

25. Allen MB, Ray SG, Leitch AG, Dhillon B, Cullen B. Steroid aerosols and cataract formation. BMJ 1989; 299: 432-433.

26. Abuekteish F, Kirkpatrick JN, Russell G. Posterior subcapsular cataract and inhaled corticosteroid therapy. Thorax 1995; 50: 674-676.

27. Agertoft L, Larsen FE, Pedersen S. Posterior subcapsular cataracts, bruises and hoarseness in children with asthma receiving long-term treatment with inhaled budesonide. Eur Respir J 1998; 12: 130135.

28. Wilson AM, Lipworth BJ. 24 hour and fractionated profiles of adrenocortical activity in asthmatic patients receiving inhaled and intranasal corticosteroids. Thorax 1999; 54: 20-26.

29. Holt PR, Lowndes DW, Smithies E, Dixon GT. The effect of an inhaled steroid on the hypothalamicpituitary-adrenal axis - which tests should be used? Clin Exp Allergy 1990; 20: 145-149.

30. Lipworth BJ. Systemic adverse effects of inhaled corticosteroid therapy: A systematic review and meta-analysis. Arch Intern Med 1999; 159: 941-955.

31. Russell G. Inhaled corticosteroid therapy in children: an assessment of the potential for side effects. Thorax 1994; 49: 1185-1188.

32. Barnes NC, Hallett C, Harris TA. Clinical experience with fluticasone propionate in asthma: a meta-analysis of efficacy and systemic activity compared with budesonide and beclomethasone dipropionate at half the microgram dose or less. Respir Med 1998; 92: 95-104.

33. Todd G, Dunlop K, McNaboe J, Ryan MF, Carson D, Shields MD. Growth and adrenal suppression in asthmatic children treated with high-dose fluticasone propionate. Lancet 1996; 348: 27-29.

34. Priftis K, Milner AD, Conway E, Honour JW. Adrenal function in asthma. Arch Dis Child 1990; 65: 838-840

35. Todd GRG, Acerini CL, Buck JJ, et al. Acute adrenal crisis in asthmatics treated with high-dose fluticasone propionate. Eur Respir J 2002; 19: 1207-1209.

36. Balfour-Lynn I. Growth and childhood asthma. Arch Dis Child 1986; 61: 1049-1055.

37. Allen DB, Mullen M, Mullen B. A meta-analysis of the effect of oral and inhaled corticosteroids on growth. J Allergy Clin Immunol 1994; 93: 967-976. 
38. Wolthers OD, Pedersen S. Short term linear growth in asthmatic children during treatment with prednisolone. BMJ 1990; 301: 145-148.

39. Wolthers OD, Pedersen S. Growth of asthmatic children during treatment with budesonide: a double blind trial. BMJ 1991; 303: 163-165.

40. Wolthers OD, Pedersen S. Short-term growth during treatment with inhaled fluticasone propionate and beclomethasone diproprionate. Arch Dis Child 1993; 68: 673-676.

41. Tinkelman DG, Reed CE, Nelson HS, Offord KP. Aerosol beclomethasone dipropionate compared with theophylline as primary treatment of chronic, mild to moderately severe asthma in children. Pediatrics 1993; 92: 64-77.
42. Doull IJ, Campbell MJ, Holgate ST. Duration of growth suppressive effects of regular inhaled corticosteroids. Arch Dis Child 1998; 78: 172-173.

43. Jonasson G, Carlsen KH, Jonasson C, Mowinckel P. Low-dose inhaled budesonide once or twice daily for 27 months in children with mild asthma. Allergy 2000; 55: 740-748.

44. Price J, Hindmarsh $\mathrm{P}$, Hughes $\mathrm{S}$, Efthimiou J. Evaluating the effects of asthma therapy on childhood growth: principles of study design. Eur Respir J 2002; 19: 1167-1178.

45. Price J, Hindmarsh $\mathrm{P}$, Hughes S, Efthimiou J. Evaluating the effects of asthma therapy on childhood growth: what can be learnt from the published literature? Eur Respir J 2002; 19: 1179-1193. 